\title{
A study of low-temperature and mountain epilithic diatom community in mountain stream at the Han River system, Korea
}

Yong Jin Kim ${ }^{1,2}$ and Ok Min Lee

\begin{abstract}
Background: This study was conducted to assess the physicochemical water quality and the altitudinal distribution of low-temperature and mountain epilithic diatom (LTMD) community in Buk and Hangae streams that are located in Seorak Mountain with the height of $1708 \mathrm{~m}$ in Korea. And the community characteristics of LTMD found in the Buk and Hangae streams were compared to that of LTMD from the Han River system.

Results: The physicochemical water qualities of Buk and Hangae streams were determined to be very clean. As a result of analyzing the community composition, 135 taxa of epilithic diatoms were determined, and 22 taxa appeared including Hannaea arcus var. subarcus which are known to have low-temperature and mountain ecological characteristics in the literatures. The relative frequencies of LTMD were 37.0 0.9\% range from the upper to lower regions. Although Diatoma tenuis, Eunotia minor, and Gomphonema affine are known to be ubiquitous in streams and lakes, in this research, the three taxa were added into low-temperature and mountain epilithic diatom, since $D$. tenuis and E. minor appeared only in altitudes above $600 \mathrm{~m}$, and $\mathrm{G}$. affine had the highest relative frequency during spring and fall in altitudes above $700 \mathrm{~m}$, when water temperature was around $10^{\circ} \mathrm{C}$.

Conclusions: Among the 24 taxa of low-temperature and mountain epilithic diatom (LTMD) (including the 3 taxa added in this study), 14 taxa (Diatoma hyemalis, D. mesodon, D. tenuis, Hannaea arcus, H. arcus var. subarcus, Ulnaria inaequalis, Eunotia bilunaris, E. implicata, E. minor, E. muscicola, E. silvahercynia, E. septena, Delicata delicatula, and Gomphonema affine) represented the characteristics of LTMD very well; they grow best in water temperatures below $15{ }^{\circ} \mathrm{C}$ in Buk and Hangae streams and Han River system.
\end{abstract}

Keywords: Altitudinal distribution, Buk and Hangae streams, Epilithic diatom, Han River system, Low-temperature and mountain

\section{Background}

Mountain streams are fragile ecosystems (Kim et al. 2012; O'Driscoll et al. 2012), sensitive to human influences such as road construction and environmental changes such as those due to climate change (Lang and Murphy 2012). Species richness in these streams is usually limited by extreme environmental conditions (Chapin and Körner 1995) and communities are therefore particularly sensitive to disturbances. Because of their sensitivity, freshwater ecosystems in these areas are useful for biodiversity and biological indicator research. Diatoms are an

\footnotetext{
* Correspondence: omlee@kyonggi.ac.kr

'Department of Life Science, Kyonggi University, lui-dong, Suwon-si 443-760, Korea

Full list of author information is available at the end of the article
}

important component in these communities. However, although diatoms play key roles in inorganic nutrient cycling involving phosphorus and silica, studies have not been conducted on these diatoms due to accessibility and economic constraints (Loeb et al. 1983; Sánchez-Castillo et al. 2008).

Diatoms respond to changes in water quality, making them useful as biological indicators (Descy 1979; Watanabe et al. 1990). Diatoms also recover quickly after habitat disturbances, compared to other organisms (Descy 1979). Additionally, changes in their biomass can indicate shifts in other environmental metrics, such as feeding by herbivores, water temperature, substrate, nutrients, flow velocity, and flow rate (Allan 1995). 
Studies on diatoms in mountain streams have been conducted in the headwaters of montane to alpine regions in Canada (Antoniades and Douglas 2002; Lauriol et al. 2006), Russia (Potapova 1996; Medvedeva 2001), Poland (Kownacki et al. 2006), and Bolivia (ServantVildary 1982). Recently, studies related to climate change and biological water assessment have been conducted, including research on the integrity of freshwater ecosystems (Falasco et al. 2012), physicochemical factors of upland blanket peat catchments (O'Driscoll et al. 2012), aquatic ecosystem monitoring, and on monitoring the integrity of biological resources and habitats. Until now, the reported diatomic indices were developed through indexing nutrients and organic matter such as the trophic diatom index (TDI) or the diatom assemblage index to organic pollution (DAIpo); however, because high altitude streams generally have relatively clean water, Falasco et al. (2012) have suggested modifying the diatomic indicators.

In Korea, only research on fishes and benthic macroinvertebrates of mountain streams has been conducted (Chung et al. 2011; Son et al. 2011), and very little research has been done on epilithic diatoms (Kim et al. 2012). Currently in Korea, nationwide biological assessments of water quality are being performed. The sites of the biological assessments of water quality are mostly in mid-lower streams; thus, the research and monitoring of mountain stream are only being done in limited areas. In addition, the appropriate indicators and indices to monitor mountain streams have not been developed; research on community composition or habitat characteristics of epilithic diatoms is insufficient.

In this study, we investigated the epilithic diatom community and physicochemical water quality parameters in the Buk and Hangae streams, the highest altitude streams in the Han River system. We focused on the distribution of low-temperature and mountain epilithic diatoms according to temperature and altitude from the literature. The aims of our research were to (i) select the indicator species that can monitor mountain stream and (ii) evaluate the applicability of the selected indicator species.

\section{Methods}

\section{Study areas and sampling sites}

The 20 sites of investigation for this research were set every $100 \mathrm{~m}$ between the Buk and Hangae streams, which flow into Soyang Lake and the Soyang River on Seorak Mountain $(1708 \mathrm{~m})$. We sampled four times in the sampling site (total of 80 samples) from May to November 2011.

The Buk stream rises from Seorak Mountain, which is the highest mountain in Korea's Han River system. The Buk stream flows into Soyang Lake, joining the Soyang
River and the Naerin stream past Baekdam (573 m), Gugokdam $(710 \mathrm{~m})$, and Gayangdong Valley $(778 \mathrm{~m})$. The distance from Gayangdong Valley to the Soyang $\operatorname{Dam}(100 \mathrm{~m})$ is $97 \mathrm{~km}$, and 13 sites $(\mathrm{BC} 01 \sim \mathrm{BC} 13)$ were investigated between the two. The Hangae stream rises from Hangaeryung $(881 \mathrm{~m})$, passes through Hangaeryung Valley (764 m), Jangsudae (652 m), and Oknyutang (365 $\mathrm{m})$, and flows into the Buk stream. The distance from Hangaeryung to the point where the Buk stream joins is $16 \mathrm{~km}$, and seven sites (HG01 HG07) were investigated between the two points (Fig. 1).

The community characteristics of LTMD found in the Buk and Hangae streams were compared to that of LTMD from the Han River system. Data from the Han River system the research results of 19 sites (220$871 \mathrm{~m}$ ) from Kim et al. (2012).

\section{Sampling and analysis methods}

The altitude at the sampling sites was measured by GPS (Triton, Magellan) and was also based on referenced data from the National Geographic Information Institute (www.ngii.go.kr). A portable meter (Horiba D-55, Orion 5-Star) was used to measure the physiochemical factors: water temperature, dissolved oxygen (DO), $\mathrm{pH}$, conductivity, and turbidity in the field. Water velocity was measured by the Craig method (Craig 1987). Chlorophyll $a$, biological oxygen demand (BOD), total nitrogen (TN), and total phosphorus (TP) were analyzed by standard methods (Greenberg et al. 2000). Rock or gravel was selected $20-30 \mathrm{~cm}$ under the water surface for attached algae sampling. Rock $\left(25-100 \mathrm{~cm}^{2}\right)$ was brushed and scraped, and the scraped material was diluted in $300 \mathrm{ml}$ distilled water. Samples were stored after fixation in Lugol's solution (Greenberg et al. 2000). Permanent slide samples were made for analysis of diatoms. Epilithic diatoms in the samples were identified using $\times 200$ to $\times$ 1000 magnification under light and phase-contrast microscopy (Olympus BX41, Japan). Species were identified in accordance with Krammer and Lange-Bertalot (1986, 1988, 1991), Krammer (2002), Lange-Bertalot et al. (2010), Round et al. (1990) and AlgaeBase (www.algaebase.org).

Illustrations, including those by Joh et al. (2010), Chung (1993), Krammer (2002), Lange-bertalot et al. (2010), Round et al. (1990); and literature, including Antoniades and Douglas (2002), Kim et al. (2009), Lee et al. (1992), Medvedeva (2001), O'Driscoll et al. (2012), Torne's et al. (2012), were referenced to make the list of LTMD that live in low-temperature or mountainous areas.

Detrended correspondence analysis (DCA) and correlation analysis were performed to assess the relationships among the number of cells, relative frequency, physicochemical factors, and altitude $(n=80)$ using PC-ORD (MjM Software, Gleneden Beach, OR, USA) and SPSS ver. 12.0 software (SPSS, Inc., Chicago, IL, USA). 


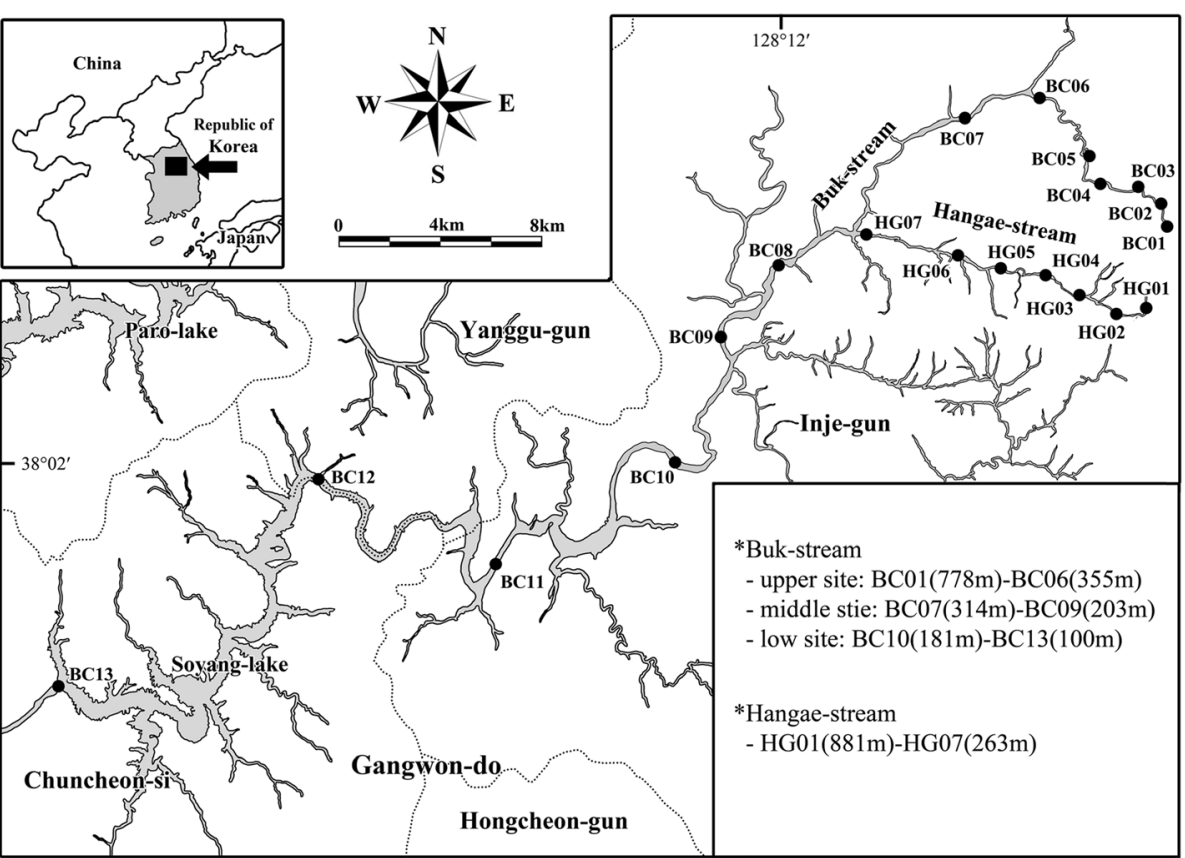

Fig. 1 A map showing the 20 sites in Buk and Hangae streams of Gangwon-do, Korea, from May to November 2011

\section{Results}

\section{Physicochemical factors}

All physicochemical factors, excluding water temperature, were subdivided into upper, middle, and lower stream reaches based on altitude and habitat environment. All Hangae stream sites were classified as upper stream reaches.

The water temperature in the Buk and Hangae streams was $8.3-26.9{ }^{\circ} \mathrm{C}$ and increased as altitude decreased (Fig. 2). The greatest difference between the highest and lowest water temperature in the Buk stream was measured in May, and the least difference was measured in August. Water temperatures at sites
BC01 to BC04, with an average altitude of $500 \mathrm{~m}$ or greater, averaged $<15{ }^{\circ} \mathrm{C}$, decreasing by $1.4{ }^{\circ} \mathrm{C}\left(r^{2}=\right.$ $0.893)$ per $100 \mathrm{~m}$ of altitude. In contrast, the greatest and least differences between the highest and lowest water temperatures were measured in August and November, respectively, in the Hangae stream. The average water temperature was $<15{ }^{\circ} \mathrm{C}$ from HG01 to HG04, sites with elevations of $>500 \mathrm{~m}$. For every $100 \mathrm{~m}$ increase in elevation, water temperature dropped by $1.1{ }^{\circ} \mathrm{C}\left(r^{2}=0.964\right)$. The $\mathrm{pH}$ of the Buk stream was slightly acidic at 6.5 , whereas the Hangae stream had a $\mathrm{pH}$ of $7.4-8.0$. The conductivity in the upper part of the Buk stream was very low with an average of

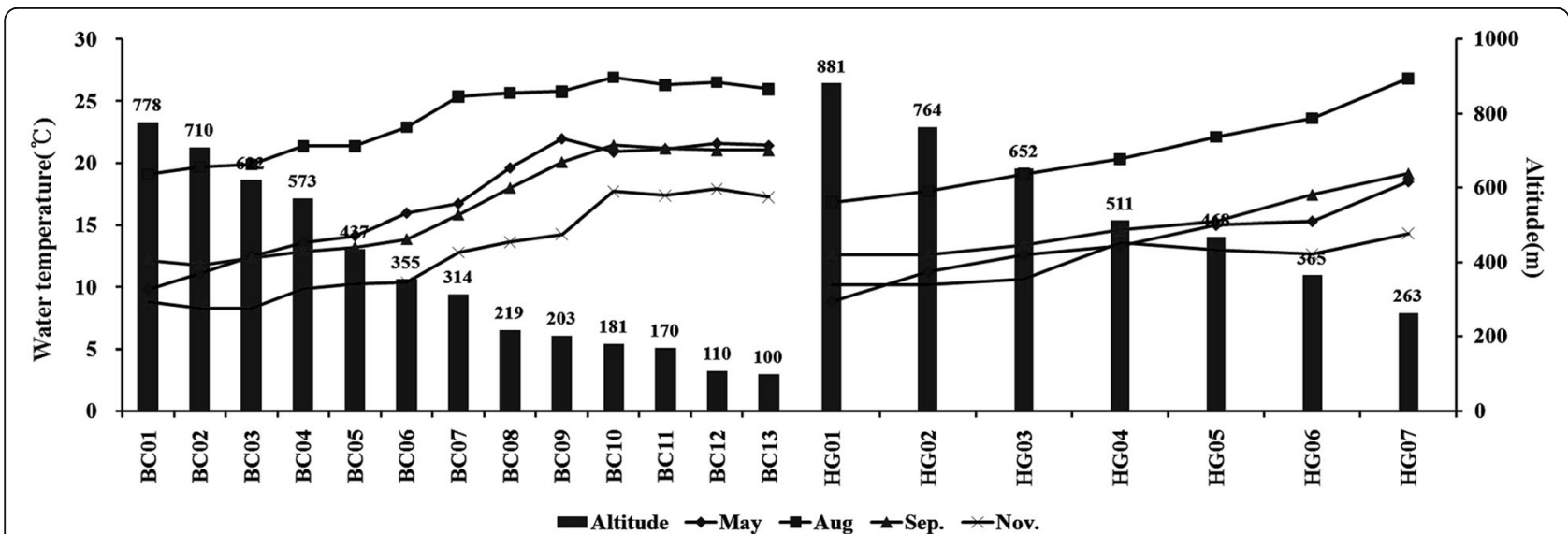

Fig. 2 Altitudinal and seasonal variations in the water temperatures of Buk (BC) and Hangae (HG) streams in Gangwon-do, Korea, from May to November 2011 
$25.9 \mu \mathrm{S} \mathrm{cm}{ }^{-1}$. The middle and lower stretches of the Buk and Hangae streams had low conductivity of $60 \mu \mathrm{S} \mathrm{cm}^{-1}$. Chlorophyll $a$ concentration in the lower Buk stream was $13.3 \mu \mathrm{g} \mathrm{L}{ }^{-1}$. In other sites, the concentration was low, averaging $\leq 1 \mu \mathrm{g} \mathrm{L}^{-1}$. The water quality was clean with an average DO consumed in 5 days $\left(\mathrm{BOD}_{5}\right)$ of $\leq 2 \mathrm{mg} \mathrm{L}^{-1}$ at all sites. The average $\mathrm{TN}$ was 1.283-1.891 $\mathrm{mg} \mathrm{L}^{-1}$ and did not show much seasonal variation. TP was $17.1-22.1 \mu \mathrm{g} \mathrm{L}^{-1}$, increasing downstream (Table 1).

Altitude was highly correlated with velocity $(r=0.73)$, $\mathrm{pH}(r=-0.66)$, water temperature $(r=-0.64)$, and TP $(r=-0.55)$. Chlorophyll $a$ showed an extremely high correlation with turbidity $(r=0.82)$ and a high correlation with TP. TN was correlated with conductivity and turbidity but not with other physicochemical factors (Table 2).

\section{Community composition and LTMD}

A total of 135 epilithic diatom taxa were identified in the Buk and Hangae streams. The least number of taxa (10-12) were found in the Hangae stream and the upper Buk stream. An average of 22 and 21 taxa appeared in the middle and lower stretches of the Buk stream, respectively. Site $\mathrm{BC} 08$, in the middle of the stream, showed the most diversity with 33 taxa collected in May. The number of taxa decreased at site $\mathrm{BC} 10$, at the inlet of Soyang Lake (Fig. 3).

From the literature in Korea, low-temperature and mountain-dwelling algae of 39 taxa were identified. Of these 39 taxa, 32 taxa were diatoms, 5 taxa were Crysophyceae, and 2 taxa were Chlorophyceae. Of the 32 taxa of diatoms in Korea, 21 taxa appeared in this study. These include Diatoma hyemalis, D. mesodon, D. moniliformis, Hannaea arcus, H. arcus var. subarcus, Ulnaria inaequalis, and Tabellaria flocculosa in Fragilariaceae;
Eunotia bilunaris, E. implicata, E. muscicola, E. silvahercynia, and E. septena in Eunotiaceae; Eucocconeis laevi and Planothidium lanceolatum of Achnanthaceae; and Cymbella aspera, C. leptoceros, C. tumida, Delicata delicatula, Reimeria. sinuata, Gomphonema acuminatum, and G. clavatum in Naviculaceae. Additionally, Diatoma tenuis, Eunotia minor, and Gomphonema affine were classified as LTMD due to their limited appearance at altitudes $>500 \mathrm{~m}$. The relative frequencies of LTMD ranged from 0.0 to $94.6 \%$, appearing more frequently in altitudes $>500 \mathrm{~m}$ (Fig. 4).

The five Eunotia species usually appeared at altitudes of $>500 \mathrm{~m}$; in particular, E. septena and E. implicata were limited to altitudes $>700 \mathrm{~m}$. Gomphonema affine showed a similar trend to that of Eunotia with a high relative frequency at altitudes $>700 \mathrm{~m}$ and a decreasing relative frequency below $600 \mathrm{~m}$. It also showed decreasing relative frequency in summer and increasing frequency in spring and fall (Fig. 5).

Hannaea arcus and $H$. arcus var. subarcus showed differences in habitat range. The appearance of $H$. arcus was limited to altitudes of $200-300 \mathrm{~m}$, whereas $H$. arcus var. subarcus showed its highest relative frequency at $400 \mathrm{~m}$, and decreased in either the upper or lower parts of the streams. Ulnaria inaequalis had high relative frequency at about $300 \mathrm{~m}$ and showed a similar range to that of $H$. arcus. Ulnaria inaequalis and $H$. arcus had a high relative frequency during spring, when they appeared at $<200 \mathrm{~m}$ (Fig. 5).

Similar to Eunotia, Diatoma hyemalis only appeared in altitudes $>700 \mathrm{~m}$, whereas $D$. tenuis was limited to about $600 \mathrm{~m}$. D. mesodon only appeared at altitudes $>700 \mathrm{~m}$ during summer when water temperature was high and appeared at around $300 \mathrm{~m}$ in the fall and spring (Fig. 5). Excluding Delicata delicatula, most taxa in Cymbellaceae appeared at low altitudes. Regardless of

Table 1 Mean values of physicochemical factor values in Buk (BC) and Hangae (HG) streams of Gangwon-do, Korea, from May to November 2011

\begin{tabular}{|c|c|c|c|c|}
\hline \multirow[t]{2}{*}{ Parameter } & \multicolumn{3}{|c|}{ Buk stream (mean \pm SD) } & \multirow{2}{*}{$\begin{array}{l}\text { Hangae stream } \\
\text { (mean } \pm \mathrm{SD})\end{array}$} \\
\hline & $\begin{array}{l}\text { Upper } \\
\text { (BC01-06) }\end{array}$ & $\begin{array}{l}\text { Middle } \\
\text { (BC07-09) }\end{array}$ & $\begin{array}{l}\text { Lower } \\
\text { (BC10-13) }\end{array}$ & \\
\hline Altitude (m) & $579.2 \pm 160.6$ & $351.2 \pm 60.0$ & $185.9 \pm 41.2$ & $503.8 \pm 219.9$ \\
\hline Velocity $\left(\mathrm{cm} \mathrm{s}^{-1}\right)$ & $65.8 \pm 19.5$ & $35.0 \pm 16.1$ & $13.7 \pm 12.8$ & $54.6 \pm 4.8$ \\
\hline Dissolved oxygen $\left(\mathrm{mg} \mathrm{L}^{-1}\right)$ & $9.3 \pm 2.1$ & $9.1 \pm 0.1$ & $10.1 \pm 0.3$ & $8.8 \pm 0.4$ \\
\hline $\mathrm{pH}$ & $6.5 \pm 0.4$ & $7.8 \pm 0.7$ & $8.0 \pm 0.1$ & $7.4 \pm 0.2$ \\
\hline Conductivity $\left(\mu \mathrm{S} \mathrm{cm}{ }^{-1}\right)$ & $25.9 \pm 4.2$ & $61 \pm 12.8$ & $60.9 \pm 6.3$ & $64.1 \pm 19.4$ \\
\hline Turbidity (NTU) & $0.8 \pm 1.0$ & $1.2 \pm 1.2$ & $12.0 \pm 4.1$ & $0.6 \pm 0.6$ \\
\hline Chlorophyll $a\left(\mu \mathrm{g} \mathrm{L}^{-1}\right)$ & $0.2 \pm 0.1$ & $1.2 \pm 0.4$ & $13.3 \pm 5.6$ & $0.6 \pm 0.2$ \\
\hline $\mathrm{BOD}_{5}\left(\mathrm{mg} \mathrm{L}^{-1}\right)$ & $0.6 \pm 0.1$ & $1.6 \pm 1.0$ & $2.0 \pm 0.8$ & $0.5 \pm 0.0$ \\
\hline Total nitrogen $\left(\mathrm{mg} \mathrm{L}^{-1}\right)$ & $1.386 \pm 0.140$ & $1.283 \pm 0.138$ & $1.891 \pm 0.152$ & $1.323 \pm 0.302$ \\
\hline Total phosphorus $\left(\mu \mathrm{g} \mathrm{L}^{-1}\right)$ & $17.7 \pm 8.3$ & $22.1 \pm 3.4$ & $49.5 \pm 6.7$ & $17.1 \pm 1.1$ \\
\hline
\end{tabular}


Table 2 Correlation comparison of physicochemical factors in Buk (BC) and Hangae (HG) streams of Gangwon-do, Korea, from May to November 2011

\begin{tabular}{|c|c|c|c|c|c|c|c|c|c|c|c|}
\hline & WT & DO & $\mathrm{pH}$ & $\mathrm{EC}$ & Tur. & Chl.a & $\mathrm{BOD}_{5}$ & TN & TP & Altitude & Velocity \\
\hline WT & 1.00 & $-0.29^{* *}$ & $0.57^{* *}$ & 0.15 & $0.51^{* *}$ & $0.44^{* *}$ & $0.44^{* *}$ & 0.03 & $0.49^{* *}$ & $-0.64^{* *}$ & $-0.51^{* *}$ \\
\hline DO & & 1.00 & 0.20 & 0.19 & 0.14 & 0.07 & 0.04 & 0.07 & 0.00 & $-0.28^{*}$ & $-.024^{*}$ \\
\hline $\mathrm{pH}$ & & & 1.00 & $0.46^{* *}$ & $0.44^{* *}$ & $0.43^{* *}$ & $0.35^{* *}$ & 0.15 & $0.41^{* *}$ & $-0.66^{* *}$ & $-0.62^{* *}$ \\
\hline Con. & & & & 1.00 & 0.07 & 0.00 & 0.09 & $0.40^{* *}$ & 0.03 & $-0.40^{* *}$ & $-0.36^{* *}$ \\
\hline Tur. & & & & & 1.00 & $0.82^{* *}$ & $0.57^{* *}$ & $0.35^{* *}$ & $0.55^{* *}$ & $-0.39^{* *}$ & $-0.41^{* *}$ \\
\hline Chl.a & & & & & & 1.00 & $0.45^{* *}$ & 0.21 & $0.56^{* *}$ & $-0.38^{* *}$ & $-0.44^{* *}$ \\
\hline $\mathrm{BOD}_{5}$ & & & & & & & 1.00 & 0.09 & $0.40^{* *}$ & $-0.38^{* *}$ & $-0.30^{* *}$ \\
\hline TN & & & & & & & & 1.00 & -0.02 & -0.02 & -0.16 \\
\hline TP & & & & & & & & & 1.00 & $-0.55^{* *}$ & $-0.60^{* *}$ \\
\hline Altitude & & & & & & & & & & 1.00 & $0.73^{* *}$ \\
\hline Velocity & & & & & & & & & & & 1.00 \\
\hline
\end{tabular}

WT water temperature, DO dissolved oxygen, EC electric conductivity, Tur. turbidity, $T N$ total nitrogen, $T P$ total phosphorus

${ }^{*} P<0.05,{ }^{*} P<0.01, n=80$

season, the relative frequency of Reimeria sinuata appeared in altitudes $200 \mathrm{~m}$. Cymbella tumida did not show a relationship with altitude or water quality, appearing at altitudes $<300 \mathrm{~m}$. Along with Reimeria sinuata, Planothidium lanceolatum showed the highest relative frequency at altitudes of $200 \mathrm{~m}$ (Fig. 5).

DCA was conducted by assigning all LTMD and all other species with a relative frequency higher than $1 \%$ to a main matrix, and assigning physicochemical factors to the second matrix. As a result, the eigenvalue of axis 1 was 0.599 and was highly correlated with factors such as water temperature, $\mathrm{pH}, \mathrm{TP}$, and $\mathrm{BOD}_{5}$, but was negatively correlated with altitude $(r=-0.809)$ and velocity $(r=-0.747)$. The eigenvalue of axis 2 was 0.346 , and it was positively correlated with water temperature, $\mathrm{pH}$, and conductivity but negatively correlated with altitude (Fig. 6).

In the graph, taxa with positive values on axis 1 show increased relative frequency when the altitude and water velocity decreased and the water temperature increased. These taxa had the greatest correlation to changes in physicochemical factors such as $\mathrm{pH}, \mathrm{BOD}_{5}$, and TP. The taxa on the positive side of axis 2 are those in which relative frequencies increased as $\mathrm{pH}$ increased. Taxa on the negative side of axis 2 decreased in relative frequency as $\mathrm{pH}$ increased. Therefore, taxa placed in the third quadrant best represent the characteristics of LTMD (Fig. 6).

\section{LTMD at other mountain streams in the Han River system} (Kim et al. 2012)

The average water temperature of the streams in the Han River system was $14.5{ }^{\circ} \mathrm{C}$, which shows the weak relationship between altitude and water temperature $\left(r^{2}=\right.$ 0.106). The relationship between altitude and water temperature seems to be greater in an area where the riverbed is rarely changed, and in riparian vegetation

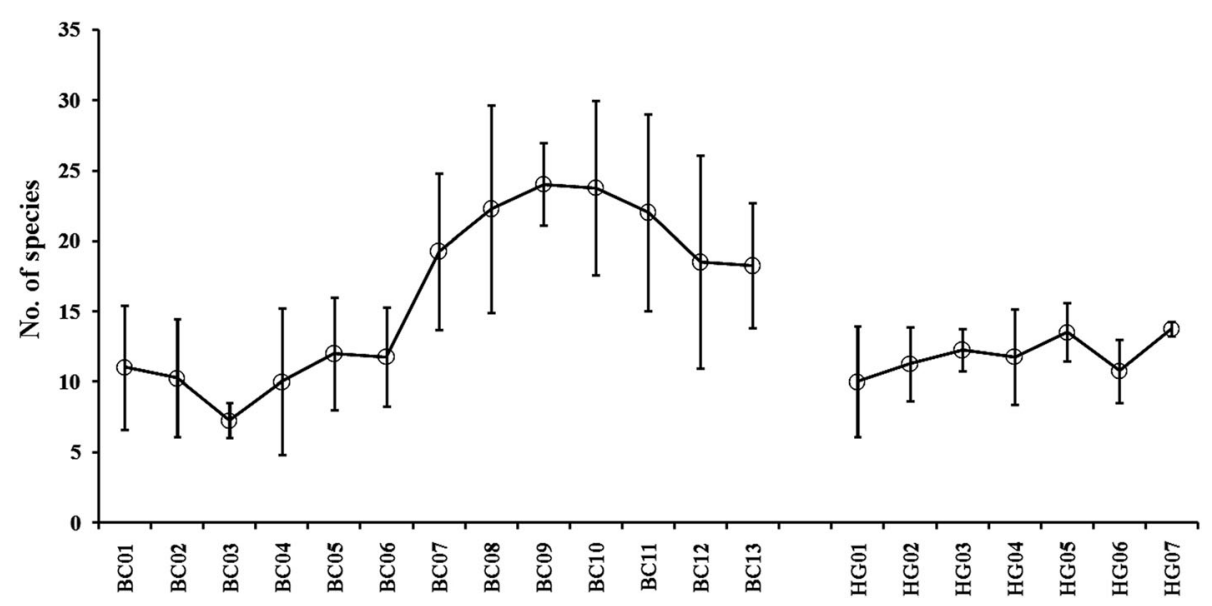

Fig. 3 The species numbers of epilithic diatom in Buk (BC) and Hangae (HG) streams of Gangwon-do, Korea, from May to November 2011 


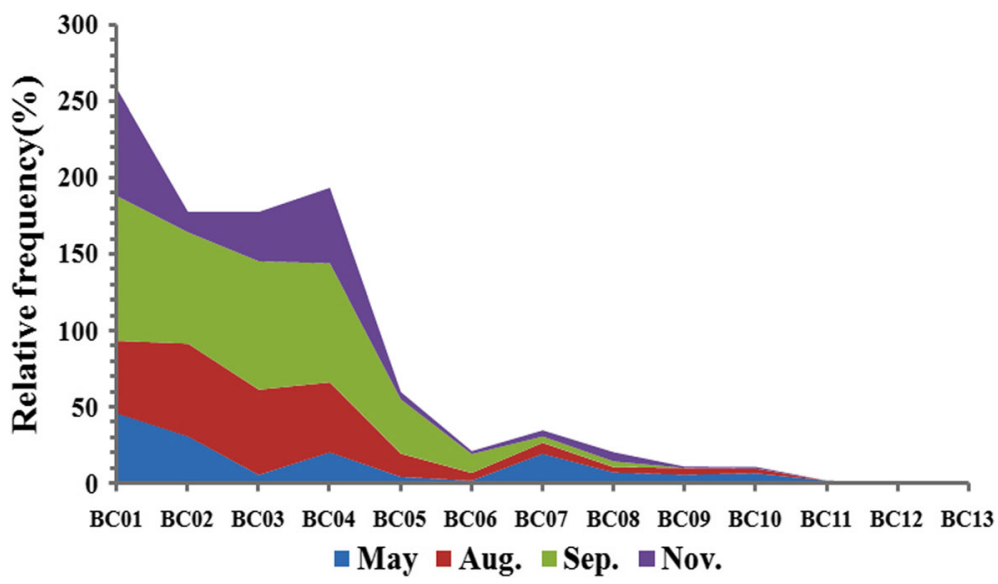

Fig. 4 Relative frequency of LTMD in Buk stream of Gangwon-do from May to November 2011

environments, such as the Buk and Hangae streams (Kim et al. 2012). The pH ranged from 6.8 to 9.5, with a large variation, depending on the area. A total of 14 taxa of LTMD were found, including Cymbella affine, $C$. tumida, Diatoma mesodon, D. vulgaris, Eunotia minor, E. pectinalis, Hannaea arcus, H. arcus var. subarcus, Planothidium lanceolatum, Psammothidium oblongellum, Reimeria sinuata, and Ulnaria inaequalis. The relative frequencies of LTMD ranged from 2.1 to $80.9 \%$, with a high average of $33.9 \%$ at sites where water temperature was $15{ }^{\circ} \mathrm{C}$ or less; the site $\mathrm{S} 6$ had the highest relative frequency, at $80.9 \%$. The relative frequency of Hannaea arcus var. subarcus at site $\mathrm{S} 6$ was $56.6 \%$; $H$. arcus var. subarcus showed the highest relative frequency among the LTMD ranging from 27.1 to $40.5 \%$ Fig. 7.

\section{Discussion}

Physicochemical factors

Of the physiochemical environmental factors examined, water temperature, $\mathrm{pH}, \mathrm{TP}$, and velocity were found to
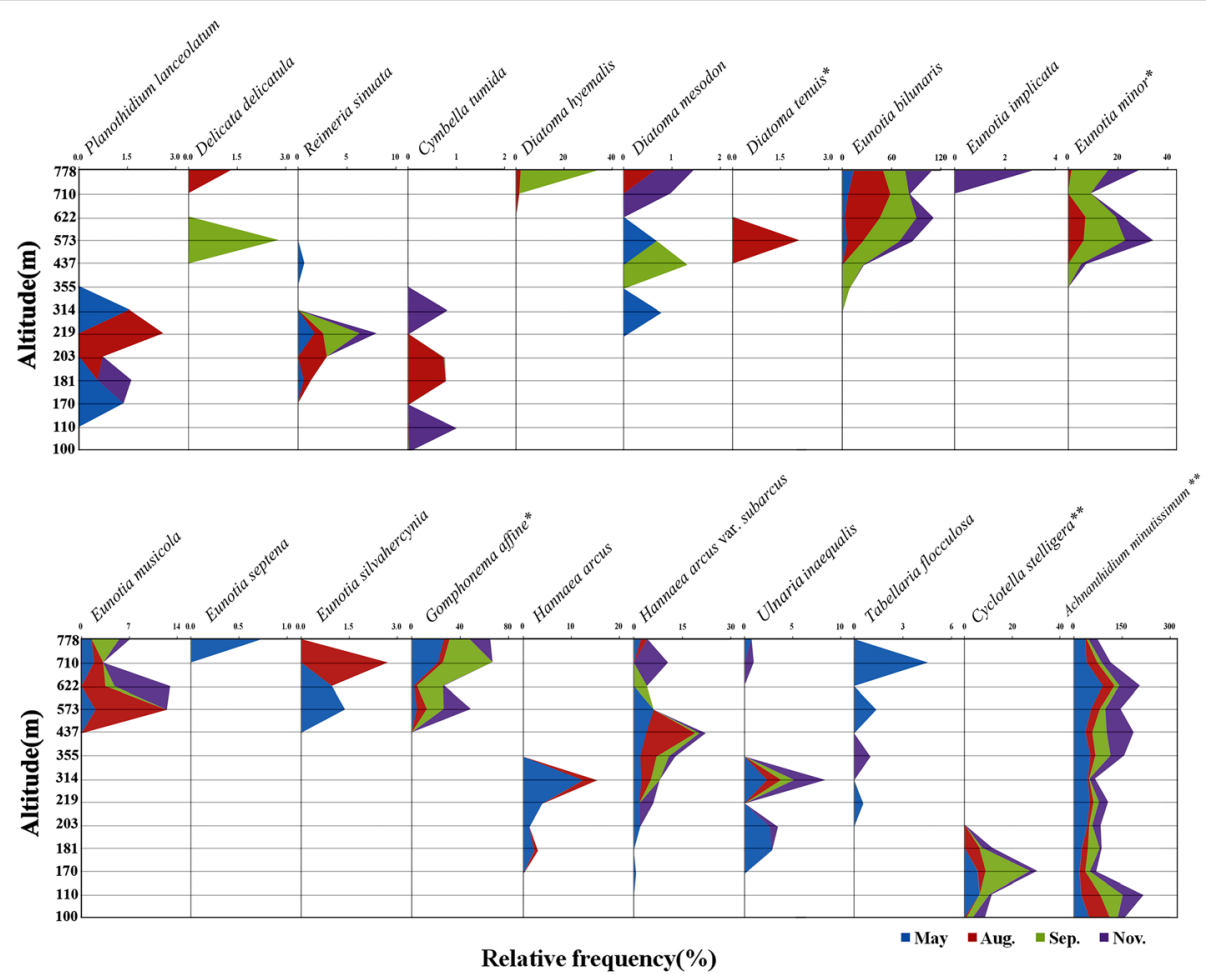

Fig. 5 The distribution of LTMD in Buk stream of Gangwon-do, Korea, from May to November 2011 ( ${ }^{*}$ added in this study; ${ }^{* *}$ taxa of widespread and lower altitude) 


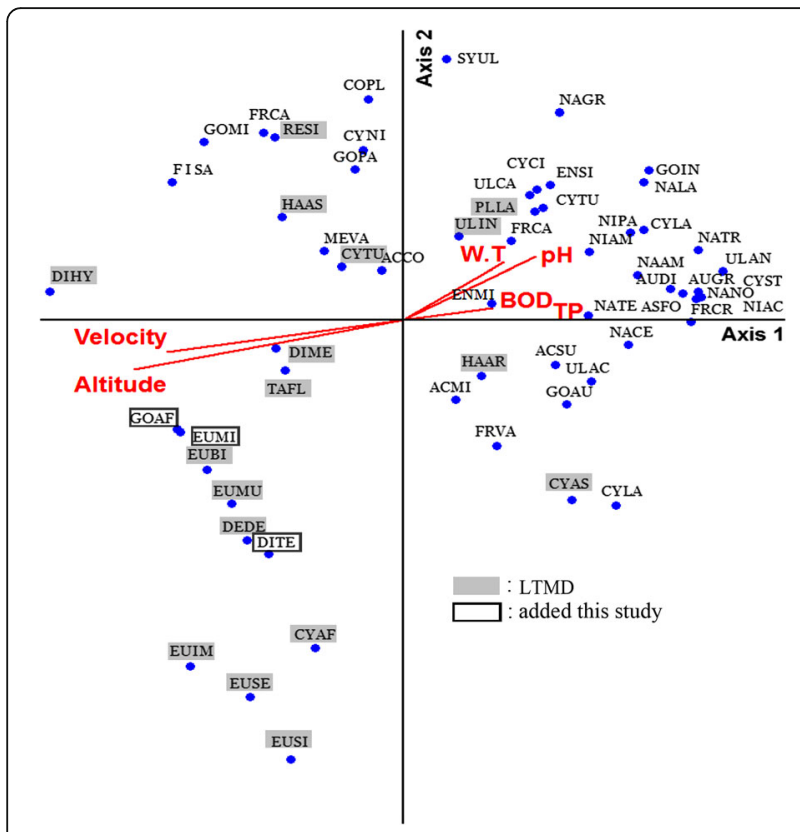

Fig. 6 Detrended correspondence analysis diagram showing diatom species (upper $1 \%$ relative frequency, LTMD) in relation to environmental variables $(n=80)$

have strong relationships with altitude. For the Buk and Hangae streams, the change in factors such as water temperature, $\mathrm{pH}$, and velocity can be sorted based on altitude of $500 \mathrm{~m}$. Based on the altitude of $500 \mathrm{~m}$, water temperature fluctuated around $15{ }^{\circ} \mathrm{C}, \mathrm{pH}$ ranged from neutral to slightly acidic, and velocity showed about $30 \mathrm{~cm} \mathrm{~s}^{-1}$ difference. The TP was greater in lower sites and showed little difference in concentration at upper and middle sites (Table 1).

The negative correlation between altitude and water temperature can only be applied to streams with ecologically similar environments (Kim et al. 2012), because they are affected by groundwater and riparian vegetation. Complementary data are needed for each ecological environment to compare between streams.

\section{Community composition and LTMD}

The 135 taxa of epilithic diatoms from the Buk and Hangae streams were similar to the 138 taxa found in high altitude streams in the Maritime Alps National Park (Falasco et al. 2012). The taxa that appeared in the upper region were not diverse. An increase in taxa due to nutrients ( $\mathrm{TP}$ and $\mathrm{TN}$ ), $\mathrm{pH}$, and water temperature was observed beginning in the middle sections of the streams. Among the Pennales, diatoms in Naviculaceae and Fragilariaceae families were most diverse. In the upper region, saproxenous taxa (Watanabe et al. 2005) including Encyonema minutum, Hannaea arcus var. subarcus, and Diatoma mesodon were detected. In the middle and lower parts of the streams, the abundance of saprophilous taxa (Kelly and Whitton 1995; Watanabe et al. 2005) such as Nitzshcia amphibian, N. palea, and Navicula gregaria of Naviculaceae and Bacillariaceae increased. Generally, the relative frequency of taxa in Navicula and Nitzschia were higher in the lower regions than those in the upper regions (Atazadeh et al. 2007; Kim et al. 2009), which was thought to be due to $\mathrm{pH}$ and nutrient concentrations (Ginn et al. 2007; Passy, 2007).

Among the 32 taxa of mountain diatoms in Korea, 21 taxa were identified in this study, and 3 additional taxa were added. The genus Eunotia best represented the characteristics of LTMD. Most taxa in the genus Eunotia appear in low pH, alpine headwaters (Joh et al. 2010, Lange-Bertalot et al. 2010). This is thought to be due to the greater effect of $\mathrm{pH}$ than water temperature on this genus. Eunotia implicata was limited to altitudes > $700 \mathrm{~m}$ (Fig. 5). The seasonal average $\mathrm{pH}$ was slightly acidic at $\leq 6.5$ (Table 1). Eunotia bilunaris had a decreasing relative frequency starting at an altitude of $500 \mathrm{~m}$, and did not appear at $300 \mathrm{~m}$, where the $\mathrm{pH}$ was 7.0. All Eunotia taxa were placed in the third quadrant of the DCA chart, which means they appeared in the high altitude, low-pH environment (Fig. 6). The seven taxa of Eunotia including E. minor showed these characteristics clearly. The newly added LTMD from this study,

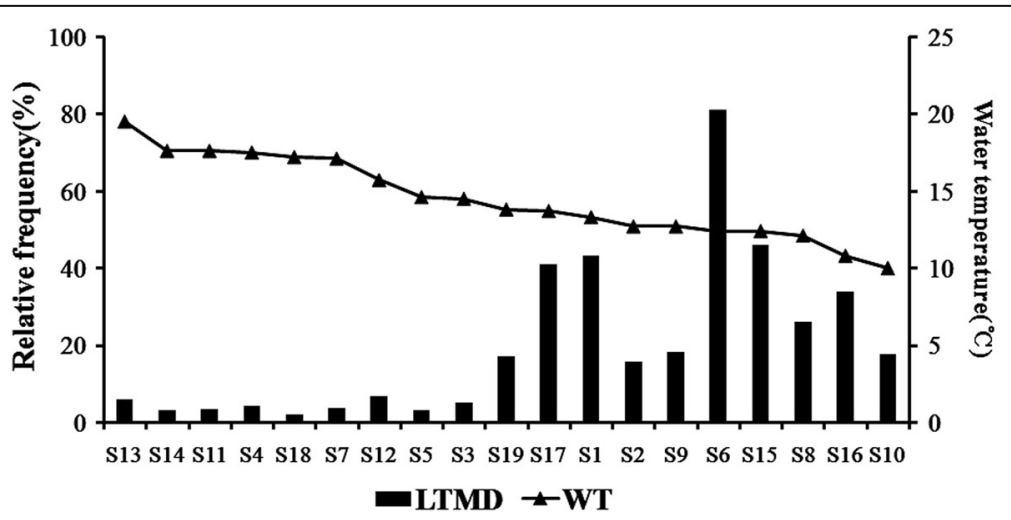

Fig. 7 The variation of temperature and distribution of LTMD in 19 sites at mountain streams in the Han River system October to November 2010 
Gomphonema affine and D. teunis, showed trends similar to those of Eunotia. In particular, during each of the four samples, G. affine showed less than $10 \%$ frequency only in August, when the water temperature was high. In altitudes above $700 \mathrm{~m}$, the frequency of appearance of G. affine did not significantly differ, based on factors such as $\mathrm{pH}$, water velocity, TN, and TP; its growth seems to be limited by water temperature.

Hannaea arcus appears as a major dominant species in the Sophia River and Sophia Lake in Canada (Antoniades and Douglas 2002). Sophia Lake and its catchment area are a low temperature water system $\left(4-11^{\circ} \mathrm{C}\right)$, located at the most northern part of Cornwallis Island $\left(75^{\circ} 06^{\prime} \mathrm{N}\right.$, $\left.93^{\circ} 36^{\prime} \mathrm{W}\right) . H$. arcus appears at 15 sites in the Sophia River and Sophia Lake catchment area, and has a high negative correlation with water temperature $\left(r^{2}=0.710\right)$. The dominance ratio changes greatly with water temperature. Although $H$. arcus was detected in the present study at relatively low altitudes of 200-300 m, it was mostly in May, when the water temperature was about $15{ }^{\circ} \mathrm{C}$. Growth of this genus was inhibited in the Buk stream, where $\mathrm{pH}$ was $\leq 7.0$ and altitudes were > $300 \mathrm{~m}$, which contrasted with the Antoniades and Douglas (2002) study, where it was found in water with a $\mathrm{pH}$ of around 8.0.

Hannaea arcus var. subarcus, a variety of $H$. arcus, was detected at the highest altitudes and had its greatest relative frequency at $400 \mathrm{~m}$. The presence of this species was positively correlated with altitude $\left(r^{2}=0.539\right)$ and negatively correlated with water temperature $\left(r^{2}=0.338\right)$ in a study by Kim et al. (2012). H. arcus var. subarcus, along with $H$. arcus, clearly exhibited the characteristics of LTMD. $H$. arcus var. subarcus seems to have greater growth range compared to that of $H$. arcus.
Ulnaria inaequalis, of the family Fragilariaceae, showed similar trends to those of $H$. arcus, although it seemed to have a greater growth range compared to that of $H$. arcus. Diatoma hyemalis and D. tenuis were detected in similar locations as those of Eunotia, with limited appearance in the upper regions of the streams. Diatoma hyemalis is usually found in alpine lowtemperature and oligotrophic water systems (Joh et al. 2010) such as in Switzerland (Robinson et al. 2010). Diatoma mesodon appeared at altitudes of 300-600 m during the spring and fall, and was seen at the highest altitude site in the summer and fall. Diatoma mesodon, as a representative mountain diatom along with $H$. arcus, is the dominant species in the Colorado River (Vavilova and Lewis 1999), the Willamette River in Oregon (Carpenter and Waite 2000), the Swiss Alps in Switzerland (Robinson and Kawecka 2005), and the Tatra River in the National Park of Poland (Kawecka and Robinson 2008). Delicata delicatula is usually found in oligotrophic mountains (Chung 1993) and was found in the upper region of the Buk stream during the summer and fall (Fig. 5). It was identified at the highest site during the summer and found at $600 \mathrm{~m}$ during the fall. Delicata delicatula was located near E. bilunaris and $E$. musicola on the DCA diagram; its range of growth seemed to be limited by $\mathrm{pH}$.

Every epilithic diatom community found in streams has different characteristics due to differences in physicochemical factors, including velocity, riverbed, turbidity, flow rate, habitat environment, $\mathrm{pH}$, conductivity, and nutrient concentrations. In the case of the Buk and Hangae streams, the physicochemical factors that affected the epilithic diatom community the most were altitude, water temperature, $\mathrm{pH}$, and TP (Fig. 7). The

Table 3 The list of low temperature and mountain diatoms (LTMD) and ecological character which appeared in this study

\begin{tabular}{|c|c|c|c|c|c|}
\hline Taxa & Code & Altitude & Season & Trophic state & Habitat character \\
\hline Delicata delicatula & DEDE & $\mathrm{U} / \mathrm{M} / \mathrm{L}$ & S/Su/A/W & Oligo & Mt \\
\hline Diatoma hyemalis & $\mathrm{DIHY}$ & U & $\mathrm{Su} / \mathrm{A}$ & Oligo & Low pH/Mt \\
\hline Diatoma mesodon & DIME & $\mathrm{U} / \mathrm{M} / \mathrm{L}$ & S/Su/A/W & Oligo/Meso/Eu & $\mathrm{Mt} / \mathrm{Lt}$ \\
\hline Diatoma tenuis & DITE & $\mathrm{U} / \mathrm{M}$ & W & Oligo/Meso & Mt \\
\hline Eunotia bilunaris & EUBI & $\mathrm{U} / \mathrm{M}$ & S/Su/A/W & Oligo/Meso & Low pH/ Mt \\
\hline Eunotia minor & EUMI & U/M & Su/A/W & Oligo/Meso & $\mathrm{Lt}$ \\
\hline Eunotia musicola & EUMU & U & S/SU/A/W & Oligo/Meso & Mt \\
\hline Eunotia implicate & EUIM & U/M/L & W & Oligo & Low pH/Mt \\
\hline Eunotia silvahercynia & EUSI & $U$ & S/A & Oligo & Low $\mathrm{pH} / \mathrm{Mt}$ \\
\hline Eunotia septena & EUSE & $\mathrm{U} / \mathrm{M}$ & S & Oligo & Mt \\
\hline Gomphonema affine & GOAF & U & S/Su/A/W & Oligo/Meso & Low pH/Mt \\
\hline Hannaea arcus & HAAR & $M / L$ & $\mathrm{~S} / \mathrm{Su}$ & Meso/Eu & $\mathrm{pH} 7.0 \sim 8.5 / \mathrm{Lt}$ \\
\hline Hannaea arcus var. subarcus & HAAS & $\mathrm{U} / \mathrm{M} / \mathrm{L}$ & S/Su/A/W & Oligo/Meso/Eu & $\mathrm{Lt}$ \\
\hline Ulnaria inaequalis & ULIN & $M / L$ & S/Su/A/W & Meso/Eu & $\mathrm{pH} 7.0 \sim 8.5 / \mathrm{Lt}$ \\
\hline
\end{tabular}

$U$ upper, $M$ middle, $L$ low, $S$ spring, Su Summer, $A$ autumn, $W$ winter, $M t$ mountain, $L t$ low temperature 
relative frequencies of LTMD were 37, 5.6, and 0.9\% from the upper, middle, and lower regions, respectively (Fig. 4). The average relative frequency was $\geq 50 \%$ at altitudes $>700 \mathrm{~m}$. Additionally, LTMD appeared in the upper region, which is to be expected, as Eunotia. bilunaris, E. implicata, $H$. arcus, Diatoma hyemalis, $D$. mesodon, D. tenuis, and Tabellaria flocculosa also appear as dominant species in high altitude streams from places such as Italy (Falasco et al. 2012), Canada (Antoniades and Douglas 2002), and Ireland (O'Driscoll et al. 2012).

Among the LTMD, $H$. arcus, $H$. arcus var. subarcus, $D$. mesodon, and S. inaequalis had similar frequency of occurrence in 19 sites at mountain streams of the Han River system, in the Buk and Hangae streams. Although a direct comparison of genus Eunotia was difficult due to low abundance, most appeared in upper streams of 19 sites in mountain streams. Genus Cymbella did not demonstrate the general characteristics of LTMD in either the Buk and Hangae streams, or mountain streams of the Han River system.

\section{Conclusions}

Among the 24 taxa of LTMD (excluding the 10 taxa with low occurrence tendencies and relative frequencies, such as genus Achnanthes and Cymbella), 14 taxa represented the characteristics of LTMD very well; they grow best in water temperatures below $15{ }^{\circ} \mathrm{C}$. These are Diatoma hyemalis, D. mesodon, D. tenuis, Hannaea arcus, $H$. arcus var. subarcus, Ulnaria inaequalis, Eunotia bilunaris, E. implicata, E. minor, E. muscicola, E. silvahercynia, E. septena, Delicata delicatula, and Gomphonema affine (Table 3).

In all, Hannaea arcus var. subarcus was found in most mountain streams; it is thought to be a useful taxon as the most representative of Korean LTMD. The occurrence of five species in the genus Eunotia were found to have a more significant relationship to $\mathrm{pH}$ than to water temperature. Therefore, they were not useful as indicator species. However, if physicochemical factors such as oligotrophy, low conductivity, and weakly acidic $\mathrm{pH}$ are considered the primary characteristics of mountain streams or headwaters, the Eunotia species could be used as indicators. Although Hannaea arcus and D. mesodon are representative of the mountain-based epilithic diatom genera found in Korea and international studies, they can be useful as indicators for increases in water temperature; however, more studies are needed to identify additional ecological characteristics. More diverse indicators are needed to obtain accurate results monitoring mountain streams using LTMD.

\section{Abbreviations}

DCA: Detrended correspondence analysis; LTMD: Low-temperature and mountain epilithic diatom
Acknowledgements

Not applicable.

\section{Funding}

This research was supported by the foundation research project of National Research Foundation of Korea (2011-0005974).

\section{Availability of data and materials}

Please contact author for data requests.

\section{Authors' contributions}

KYJ carried out the design of the study, performed the fieldwork, and drafted the manuscript. LOK participated in the design and coordination of manuscript and helped draft the manuscript. All authors read and approved the final manuscript.

Ethics approval and consent to participate

Not applicable.

Consent for publication

Not applicable.

\section{Competing interests}

The authors declare that they have no competing interests.

\section{Publisher's Note}

Springer Nature remains neutral with regard to jurisdictional claims in published maps and institutional affiliations.

\section{Author details}

'Department of Life Science, Kyonggi University, lui-dong, Suwon-si 443-760, Korea. ${ }^{2}$ Han River Environment Research Center, National Institute of Environmental Research, 68 42, Dumulmeorigil Yangseo-myeon, Yangpyong-gun, Gyunggi Province 473-823, Korea.

Received: 16 April 2017 Accepted: 2 August 2017

Published online: 15 August 2017

\section{References}

Allan, J. D. (1995). Stream ecology-structure and function of running waters. London: Chapman and Hall.

Antoniades, D. M.. \& Douglas, M. S. V. (2002). Characterization high arctic stream diatom assemblages from cornwallis island, Nunavut, Canada. Canadian Journal of Botany, 80, 50-58.

Atazadeh, I., Sharifi, M., \& Kelly, M. G. (2007). Evaluation of the trophic diatom index for assessing water quality in river Gharasou, western Iran. Hydrobiologia, 589, 165-173.

Carpenter, K. D., \& Waite, I. R. (2000). Relations of habitat-specific algal assemblages to land use and water chemistry in the Willamette basin, Oregon. Environmental Monitoring and Assessment, 64, 247-257.

Chapin, F. S. III \& Körner, C. (1995). Patterns, causes, changes and consequences of biodiversity in arctic and alpine ecosystems. In: Arctic and alpine biodiversity: Patterns, causes and ecosystem consequences (Ed. by F.S. Chapin III and C. Körner), pp. 313-320. Springer-Verlag, Berlin.

Chung, J. (1993). Illustration of the freshwater algae of Korea. Seoul: Academy Publishing Company.

Chung, N. I., Park, B. K., \& Kim, K. H. (2011). Potential effect of increased water temperature on fish habitats in Han-river watershed. Journal of Korean Society on Water Environment, 27, 314-321.

Craig, D. A. (1987). Some of what you should know about water. Journal of North American Benthological Society, 4, 178-182.

Descy, J. P. (1979). New approach to water quality estimation using diatoms. Nova Hedwigia, 64, 305-323.

Falasco, E., Ector, L., Ciaccio, E., Hoffmann, L., \& Bona, F. (2012). Alpine freshwater ecosystems in a protected area: A source of diatom diversity. Hydrobiologia, $695,233-251$.

Ginn, B. K., Cumming, B. F., \& Smol, J. P. (2007). Diatoms-based environmental inferences and model comparisons from 494 northeastern north American lakes. Journal of Phycology, 43, 647-661. 
Greenberg, A. E., Clesceri, L. S., \& Eaton, A. N. (2000). Standard method for the examination of water and wastewater (21st ed.). Washington, D.C., USA: American Public Health Association.

Joh, G. J., Lee, J. H., Lee, K., \& Yoon, S. K. (2010). Algal flora of Korea, Volume 3 Number 2, Freshwater Ditoms II (Chrysophyta, Bacillariophyceae, Pennales, Araphidineae, Diaomaceae) (p. 153). Korea: National Institute of Biological Resources.

Kawecka, B., \& Robinson, C. T. (2008). Diatom communities of lake/stream networks in the Tatra Mountains, Poland, and the Swiss alps. Oceanological and Hydrobiological Studies, 37, 21-35.

Kelly, M. G., \& Whitton, B. A. (1995). The trophic diatom index: A new index for monitoring eutrophication in rivers. Journal of Applied Phycology, 7, 433-444.

Kim, Y. J., Kong, D. S., \& Lee, O. M. (2012). The community of cryophilic and mountain periphyton at high altitude streams in the Han-river system. Journal of Environmental Impact Assessment, 21, 143-160.

Kim, Y. J., Shin, K. A., \& Lee, O. M. (2009). Water quality assessed by DAlpo and TDI of Bokha stream and Dal stream in south Han-river, Korea. Journal of Environmental Biology, 27, 414-424

Kownacki, A., Dumnicka, E., Kwandras, J., Galas, J., \& Ollik, M. (2006). Benthic communities in relation to environmental factors in small high mountain ponds threatened by air pollutants. Boreal Environment Research, 11, 481-492.

Krammer, K. (2002). Cymbella. In Diatoms of Europe 3(Ed. By H. Lange-berralot), A. R. G. Gantner Verlag K. G., Ruggell.

Krammer, K. \& Lange-Bertalot, H. (1986). Bacillariophyceae. 1. Teil: Naviculaceae. In Süßwasserflora von Mitteleuropa(Ed. By H. Ettl, J. Gerloff, H. Heynig and D. Mollenhauer), Vol. 2/1. G. Fischer, Stuttgart and New York.

Krammer, K. \& Lange-Bertalot, H. (1988). Bacillariophyceae. 2. Teil: Bacillariaceae, Epithemiaceae, Surirellaceae. In Süßwasserflora von Mitteleuropa(Ed. By H. Ettl, J. Gerloff, H. Heynig and D. Mollenhauer), Vol. 2/2. G. Fischer, Stuttgart and New York.

Krammer, K. \& Lange-Bertalot, H. (1991). Bacillariophyceae. 4. Teil: Achnanthaceae Kritische Ergänzungen zu Navicula(Lineolatae) und Gomphonema, Gesamtliteraturverzeichnis. In Süßwasserflora von (Ed. By H. Ettl, J. Gerloff, H. Heynig and D. Mollenhauer), Vol. 2/4. G. Fischer, Stuttgart and New York.

Lang, P., \& Murphy, J. (2012). Environmental drivers, life strategies and bioindicator capacity of bryophyte communities in high-latitude headwater streams. Hydrobiologia, 679, 1-17.

Lange-Bertalot, H., Bak, M. \& Witkowski, A. (2010). Eunotia and some related genera. In Diatoms of Europe 6(Ed. by H. Lange-Bertalot), A. R. G. Gantner Verlag K. G., Ruggell.

Lauriol, B., Préevost, C., \& Lacelle, C. (2006). The distribution of diatom flora in ice caves of the northern Yukon territory, Canada: Relationship to air circulation and freezing. International Journal of Speleology, 35, 83-92.

Lee, J. H., Gotoh, T., \& Chung, J. (1992). Diatoms of Yungchun dam reservoir and its tributaries. Kyung pook prefecture, Korea. Diatom, 7, 45-70.

Loeb, S. L., Reuter, J. E. \& Goldman, C. R. (1983). Littoral zone production of oligotrophic lakes. In Periphyton of freshwater ecosystems (Ed. by R.G. Wetzel). Junk W. Publishers, The Hague.

Medvedeva, L. A. (2001). Biodiversity of aquatic algal communities in the SikhoteAlin biosphere reserve (Russia). Cryptogamie Algologie, 22, 65-100.

O'Driscoll, C., Eyto, E., Rodgers, M., O'Connor, M., Asam, Z. Z., \& Xiao, L. (2012). Diatom assemblages and their associated environmental factors in upland peat forest rivers. Ecological Indicators, 18, 443-451.

Passy, S. I. (2007). Diatom ecological guilds display distinct and predictable behavior along nutrient and disturbance gradients in running waters. Aquatic Botany, 86, 171-178.

Potapova, M. (1996). Epilithic algal communities in rivers of the Kolyma mountains, NE Siberia, Russia. Nova Hedwigia, 63, 3-4.

Robinson, C. T., \& Kawecka, B. (2005). Benthic diatoms of an alpine stream/lake network in Switzerland. Aquatic Science, 67, 492-506.

Robinson, C. T., Kawecka, B., Füreder, L., \& Peter, A. (2010). Biodiversity of flora and fauna in alpine waters. Alpine Waters, 6, 193-223.

Round, F. E., Crawford, R. M., \& Mann, D. G. (1990). The diatoms. New York, USA: University of Cambridge.

Sánchez-Castillo, P. M., Linares-Cuesta, J. E., \& Fernández-Moreno, D. (2008). Changes in epilithic diatom assemblages in a Mediterranean high mountain lake(Laguna de la caldera, sierra Nevada, Spain) after a period of drought. Journal of Limnology, 76, 49-55.
Servant-vildary, S. (1982). Altitudinal zonation of mountainous diatom flora in Bolivia: Application to the study of the quaternary. Acta Geologica Academiae Scientiarum Hungaricae, 25, 179-210.

Son, S. H., Kim, J. Y., Jo, J. J., \& Kong, D. S. (2011). Altitudinal distribution aspect of benthic macroinvertebrates in a mountain stream of Seoraksan. Journal of Korean Society on Water Environment, 27, 680-688.

Tornés, E., Leira, M., \& Sabater, S. (2012). Is the biological classification of benthic diatom communities concordant with ecotypes? Hydrobiologia, 695, 44-51.

Valvilova, V. V., \& Lewis, W. M. J. (1999). Temporal and altitudinal variations in the attached algae of mountain streams in Colorado. Hydrobiologia, 193, 81-93.

Watanabe, T., Asai, K., \& Houki, A. (1990). Numerical simulation of organic pollution in flowing waters. Hazardous Waste Containment and Treatment, 4, 251-281.

Watanabe, T., Ohtsuka, T., Tuji, A., \& Houki, A. (2005). Picture book and ecology of the freshwater diatoms. Tokyo: Uchida-rokakuho.

\section{Submit your next manuscript to BioMed Central and we will help you at every step:}

- We accept pre-submission inquiries

- Our selector tool helps you to find the most relevant journal

- We provide round the clock customer support

- Convenient online submission

- Thorough peer review

- Inclusion in PubMed and all major indexing services

- Maximum visibility for your research

Submit your manuscript at www.biomedcentral.com/submit

) Biomed Central 